\title{
Assessment of Wood Biomass Productivity from Anthocephalus macrophyllus Forest Plantation for Energy Production
}

\author{
Ahmad Mukhdlor ${ }^{1}$ Muhammad Taufiq Haqiqi ${ }^{1}$ Muhammad Taufan Tirkaamiana ${ }^{2}$ \\ Wiwin Suwinarti ${ }^{1}$ Rudianto Amirta ${ }^{1, *}$
}

${ }^{1}$ Faculty of Forestry, Mulawarman University, Samarinda 75124, Indonesia

${ }^{2}$ Faculty of Agriculture, University of 17 August 1945, Samarinda 75124, Indonesia

*Corresponding author. Email: ramirta@fahutan.unmul.ac.id

\begin{abstract}
Antocephalus macrophyllus is one of the fast-growing species widely planted in an industrial forest plantation in Indonesia. Since its cultivation has been mainly expanded, the interest to explore A. macrophyllus wood for further utilization to produce various valuable products is also growing. Nevertheless, there was no available information about energy production generated from A. macrophyllus forest plantation in recent times. Therefore, this work assessed its suitability for energy purposes. The result showed that the harvest cycle of $A$. macrophyllus plantation in third year demonstrated the most appropriate energy feedstock since it could obtain the highest wood productivity (43.20 ton/ha) with high annual energy potential (211.97 GJ/ha/year). According to the wood physicochemical properties, we found that higher lignin content contributed to an increase in calorific value. Meanwhile, the high presence of moisture had a converse effect. Finally, we suggested that the forest plantation of A. macrophyllus was promising for developing renewable and sustainable energy production in the future.
\end{abstract}

Keywords: Anthocephalus macrophyllus, Energy, Forest Plantation, Woody Biomass.

\section{INTRODUCTION}

Industrial development is the primary reason for releasing high greenhouse gas (GHG) emissions into the atmosphere [1]. It strongly contributes to severe climate change. On the other hand, the human population is growing exponentially, causing an increase in energy demand. However, the most utilized energy source is still dominated by non-renewable fossil fuels (80\%) [2]. Hence, developing alternative energy sources is necessary to improve energy security and reduce adverse problems because of conventional fuels.

Lignocellulosic biomass is one of the most popular bioenergy sources used in many countries in the world. This type of biomass accounts for more than $80 \%$ of the total biomass used in renewable energy sectors [3]. Biomass-based energy has great potential to minimize the environmental impact due to GHG emission. Its sustainable production has been reported to constitute the pillar of socioeconomic growth and reduces some wastes [4]. A lignocellulosic crop with a shorter growing ability and without compromising food production will fit sustainable green energy generation requirements. Some countries geographically located in the tropical region receive significant benefits to obtain high biomass yield since plants can grow faster than other areas on the earth. Several works have been performed to evaluate some tropical woody species [5$8]$.

Anthocephalus macrophyllus (red jabon) is a woody non-food crop. It is well known as one of the fastgrowing species widely planted in Indonesia's industrial forest plantation. A. macrophyllus wood is commonly utilized to supply needs in the pulp and paper industry. Although its cultivation has been expanded largely, there was still no available information about its potential application in energy purposes in recent times.

Therefore, this work aims to point out A. macrophyllus forest plantation's suitability for sustainable feedstock of energy production. The wood productivity of A. macrophyllus at different ages was 
assessed to obtain the most appropriate time for its harvest cycle. Furthermore, its wood physicochemical properties produced at the optimized harvest cycle time were also reported.

\section{MATERIALS AND METHODS}

\subsection{Study Area}

The research was conducted at permanent sampling plots (PSP) in an industrial forest plantation company, PT Intraca Lestari, located at Malinau district, North Kalimantan Province, Indonesia.

\subsection{Determination of Wood Biomass Productivity}

The data of plant height, diameter, and quantity (different plant age) at PSP were collected to estimate the availability of wood volume per hectare. Furthermore, the wood density of A. macrophyllus was measured according to the protocol previously reported by Henry et al. [9]. The biomass productivity was calculated based on the multiplication between volume per hectare $\left(\mathrm{m}^{3}\right)$ and its wood density $\left(\mathrm{kg} / \mathrm{m}^{3}\right)$.

\subsection{Wood Energy Potency Analysis}

The wood calorific value was measured using a bomb calorimeter according to the EN-ISO 15400:2011. The all-wood physicochemical properties obtained from the optimized harvest cycle time of A. macrophyllus forest plantation was further investigated. The content of ash, volatile matter and fixed carbon was determined following the ASTM D 7582-12. The elemental compositions such as carbon $(\mathrm{C})$, hydrogen $(\mathrm{H})$, and oxygen (O) was estimated by using an Equation introduced by Parikh et al. [10]. Other compositions, including extractive, holocellulose, $\alpha$-cellulose, and klason lignin, were carried out based on the standard of TAPPI T 222 om-98.

\section{RESULTS AND DISCUSSION}

\subsection{Wood Productivity and Energy Potency}

The diameter at breast height (DBH) increment of $A$. macrophyllus was measured. Figure 1 showed the wood samples harvested randomly from PSP at different age from the $1^{\text {st }}$ to $4^{\text {th }}$ year. It was observed that $\mathrm{DBH}$ was highly increased at $1^{\text {st }}, 2^{\text {nd }}$, and $3^{\text {rd }}$-year plant age with the mean value of $7.44,12.32$, and $15.58 \mathrm{~cm}$, respectively. It was found that an increase in DBH from $3^{\text {rd }}$ to $4^{\text {th }}$ year was relatively low, showed by the fact that the DBH increment was less than $2 \mathrm{~cm}$. In line with this, the plant height also demonstrated a similar pattern. The plant height at $1^{\text {st }}$ year $(1.50 \mathrm{~m})$ increased dramatically to $5.43 \mathrm{~m}$ at $2^{\text {nd }}$ year, followed by 8.83 and $10.58 \mathrm{~m}$ at $3^{\text {rd }}$ and $4^{\text {th }}$ year, respectively. However, these results were still lower than those of Acacia mangium, and Eucalyptus pellita previously reported $[11,12]$.
(A)

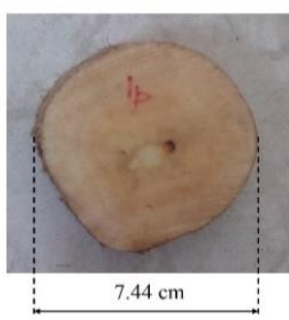

(C)

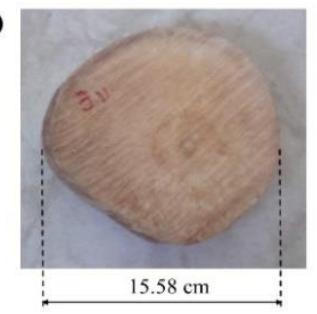

(B)

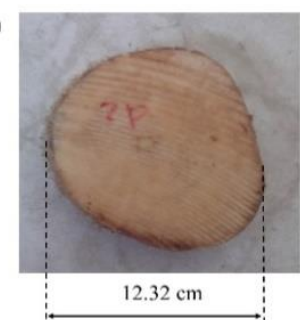

(D)

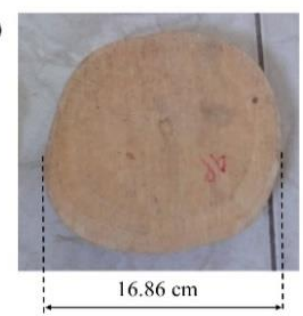

Figure 1 The appearance with each average DBH of $A$. macrophyllus wood collected from different plant age: (A) $1^{\text {st }}$ year, (B) $2^{\text {nd }}$ year, (C) $3^{\text {rd }}$ year, and (D) $4^{\text {th }}$ year.

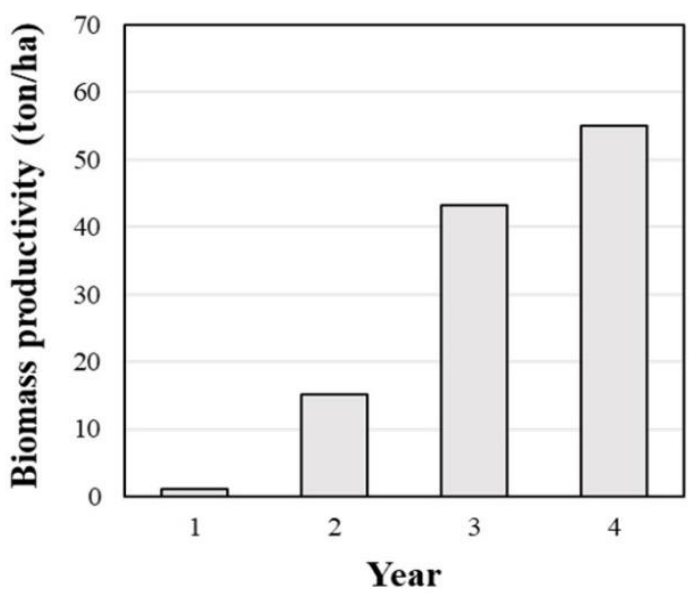

Figure 2 Wood biomass productivity obtained from $A$. macrophyllus forest plantation at different plant age.

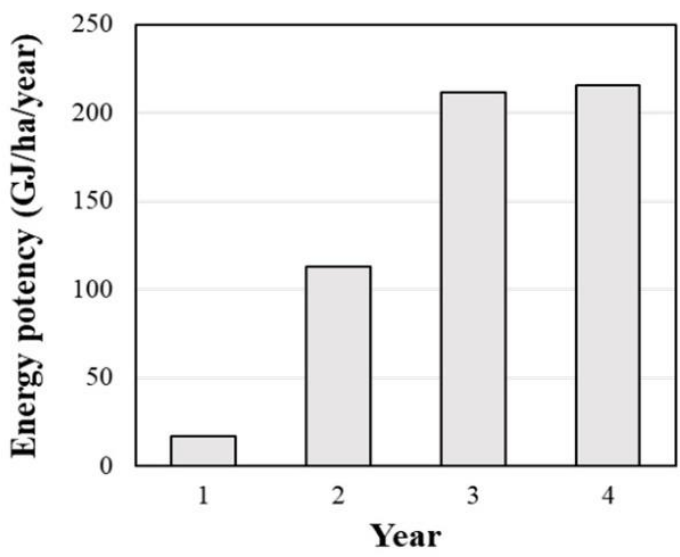

Figure 3 The annual increment of energy potency obtained from A. macrophyllus forest plantation. 
The biomass productivity of A. macrophyllus forest plantation has been displayed in Figure 2. It could be observed that the values were also rising in line with the age of the plant. It could produce 1.17 tons of biomass per hectare in $1^{\text {st }}$ year. While, in the $2^{\text {nd }}$ year, the biomass productivity achieved 15.10 ton/ha. This value was also increased in the $3^{\text {rd }}$ year (43.20 ton/ha). A. macrophyllus achieved 55.11 ton/ha biomass at the $4^{\text {th }}$ plant age. To point out the energy potency, the calorific value should be determined. The obtained value was further converted according to wood biomass availability. Figure 3 demonstrated the results of energy potency obtained from A. macrophyllus forest plantation. It could be seen that the value in the $4^{\text {th }}$ year was not significantly higher than that of the $3^{\text {rd }}$ year. Hence, the $3^{\text {rd }}$ plant age indicated the most appropriate harvest time, producing $211.97 \mathrm{GJ} / \mathrm{ha} /$ year energy potential. It was interesting to know that the normal harvest cycle time of A. macrophyllus was reportedly between 8-12 year [13]. In this study, the optimized harvest period could become faster than the common $A$. macrophyllus forest plantation to provide wood for the pulp and paper industry.

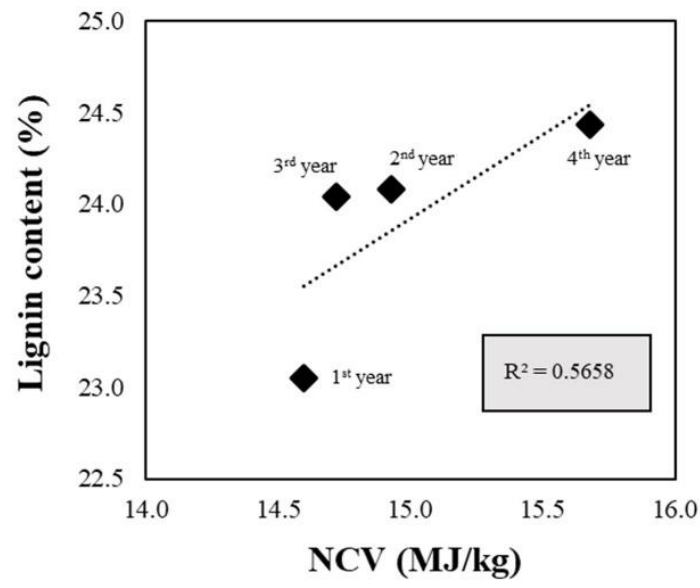

Figure 4 A correlation between lignin content and calorific value of A. macrophyllus wood.

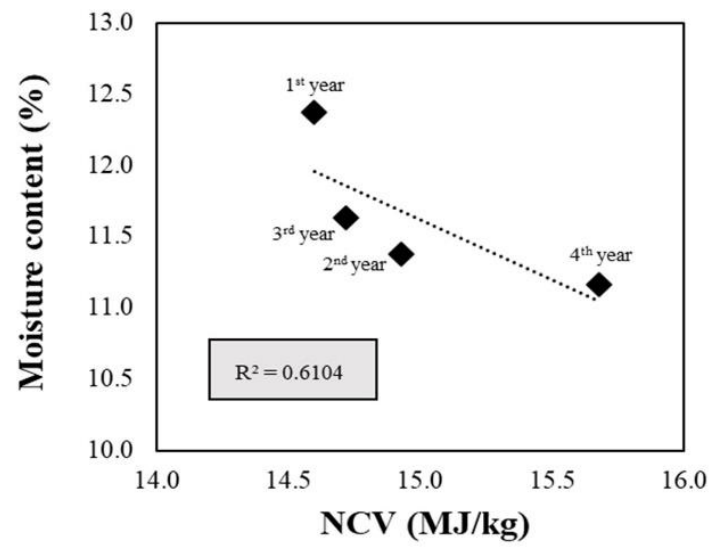

Figure 5 A correlation between moisture content and calorific value of A. macrophyllus wood.
Determination of several factors affecting the $A$. macrophyllus net calorific value (NCV) was conducted. Figure 1 showed how a high lignin content on the wood of A. macrophyllus affected its increased NCV. It was noted that the relationship between lignin and heating value was also available in the literature. Demirbas et al. reported that lignin's heat content is generally higher than other lignocellulosic components due to its richness in carbon content [14]. Lignin contains alkylphenol structures that make it potential for carbon sources, thus increasing its obtained NCV in biomasses. The heating value of lignin has been reported previously (27.0 $\mathrm{MJ} / \mathrm{kg}$ ), and this value was significantly higher in comparison to cellulose $(17.5 \mathrm{MJ} / \mathrm{kg}$ ) and hemicellulose (16.0 MJ/kg) [15]. Another property reportedly causing high calorific value is extractive. Although the previous work proved that extractive presence had a considerable increase in obtained calorific value [16], we found a contrary result (data was not shown).

Figure 2 showed an influence of moisture content on A. macrophyllus on its decreased NCV. A decrease in NVC was due to the heat of vaporization of water content [17]. The presence of moisture that played a negative role in the calorific value in biomass has been reported by several authors $[18,19]$. In general, we observed that as an increase in plant age of $A$. macrophyllus, lignin content was increased, and moisture content was decreased. Thus, it contributed to an enhancement of the obtained NCV.

\subsection{Wood Physicochemical Properties at the Optimized Plant Age}

The wood physicochemical properties of $A$. macrophyllus harvested in the third year was further assessed since it was the most desired wood for feedstock of biomass-based energy production. The wood characteristic was classified as proximate content, ultimate content, and biomass composition (Table 1).

Table 1. The wood physicochemical properties of $A$. macrophyllus obtained at the $3^{\text {rd }}$ year of plant age.

\begin{tabular}{clc}
\hline No & \multicolumn{1}{c}{ Property } & Percentage (\%) \\
\hline 1 & Ash & $0.65 \pm 0.03$ \\
2 & Volatile matter & $73.22 \pm 0.07$ \\
3 & Fixed carbon & $17.41 \pm 0.06$ \\
\hline 4 & $\mathrm{C}$ & $47.78 \pm 0.01$ \\
5 & $\mathrm{H}$ & $5.10 \pm 0.01$ \\
6 & $\mathrm{O}$ & $47.02 \pm 0.01$ \\
\hline 7 & Extractive & $3.13 \pm 0.30$ \\
8 & Holocellulose & $68.67 \pm 0.33$ \\
9 & a-cellulose & $36.06 \pm 0.50$ \\
10 & Klason lignin & $24.04 \pm 0.17$ \\
\hline
\end{tabular}

Data were presented as mean value \pm standard deviation $(n=3)$. 
The proximate content of A. macrophyllus wood included ash $(0.65 \%)$, volatile matter $(73.22 \%)$, and fixed carbon (17.41\%). Since the ash content was low, it indicated great suitability for energy feedstock via thermochemical process [20]. A previous study reported that ash content in biomass could significantly affect decreased calorific value [21]. The volatile matter represents the mass evolved at the temperature between $100^{\circ} \mathrm{C}$ and $550^{\circ} \mathrm{C}$. The high volatile content in biomass indicated better combustion and gasification rates [22]. Furthermore, a sensible fixed carbon also one of the parameters of ideal energy produced from biomass [23]. The ultimate content of A. macrophyllus wood, including $\mathrm{C}, \mathrm{H}$, and $\mathrm{O}$, was also analyzed. As shown in Table 1, the proportion of $\mathrm{C}$ and $\mathrm{O}$ was comparable with the value of 47.78 and $47.02 \%$, respectively, while the percentage of $\mathrm{H}$ was $5.10 \%$. When heated at $200-400^{\circ} \mathrm{C}$, the cellulose and hemicellulose in biomass were decomposed to produce synthetic gases [24]. On the other hand, lignin was reported to possess higher fixed carbon [25]. In this study, A. macrophyllus wood contained $68.67 \%$ holocellulose, $36.06 \%$-cellulose, and $24.04 \%$ klason lignin.

\section{CONCLUSIONS}

In summary, the biomass productivity and energy potency of $A$. macrophyllus increased annually from the first to fourth year. The third plant age was the most desired harvest circle time since it produced the highest wood productivity and energy potency value. Moreover, the increase in plant age was also linked with the enhance of lignin content. On the other hand, we found that moisture content decreased, affecting the significant enhancement on NCV value. The low proportion of ash indicated that wood of $A$. macrophyllus was acceptable for energy feedstock. Finally, we concluded that $A$. macrophyllus forest plantation was promising for future development in biomass-based energy production.

\section{AUTHORS' CONTRIBUTIONS}

AM: Methodology, Writing - original draft. MTH: Conceptualization, Writing - review \& editing. MTT: Resources. RA: Conceptualization, Funding acquisition, review and Supervision.

\section{ACKNOWLEDGMENTS}

This work was financially supported by the Faculty of Forestry, Mulawarman University. The authors are grateful to Mr Yuliansyah and Mr Supriadi for handling wood component analysis and physicochemical properties of wood biomass.

\section{REFERENCES}

[1] Y.L. Lin, N.Y. Zheng, C.S. Lin, Repurposing Washingtonia filifera petiole and Sterculia foetida follicle waste biomass for renewable energy through torrefaction. Energy 2021, p.120101. DOI: https://doi.org/10.1016/j.energy.2021.120101.

[2] E.T. Sayed, T. Wilberforce, K. Elsaid, M.K.H. Rabaia, M.A. Abdelkareem, K.J. Chae, A.G. Olabi, A.G., A critical review on Environmental Impacts of Renewable Energy Systems and Mitigation Strategies: Wind, Hydro, Biomass and Geothermal. Science of The Total Environment 2020, 766, p. 144505 .

DOI: https://doi.org/10.1016/j.scitotenv.2020.144505.

[3] M.H. Jahangir, R. Cheraghi, Economic and environmental assessment of solar-wind-biomass hybrid renewable energy system supplying rural settlement load. Sustainable Energy Technologies and Assessments 2020, 42, p.100895. DOI: https://doi.org/10.1016/j.seta.2020.100895.

[4] B. Dubis, K.J. Jankowski, D. Załuski, M. Sokólski, The effect of sewage sludge fertilization on the biomass yield of giant miscanthus and the energy balance of the production process. Energy 2020, 206, p.118189. DOI: https://doi.org/10.1016/j.energy.2020.118189.

[5] R. Amirta, Yuliansyah, E.M. Angi, B.R. Ananto, B. Setiyono, M.T. Haqiqi, H.A. Septiana, M. Lodong, R.N. Oktavianto, Plant diversity and energy potency of community forest in East Kalimantan, Indonesia: Searching for fast growing wood species for energy production. Nusantara Bioscience 2016, 8(1), pp.22-31. DOI: https://doi.org/10.13057/nusbiosci/n080106

[6] M.T. Haqiqi, W. Suwinarti, R. Amirta, Response surface methodology to simplify calculation of wood energy potency from tropical short rotation coppice species, In: IOP Conference Series: Earth and Environmental Science 2018, 144(1), p.012041. DOI: 10.1088/1755-1315/144/1/012041.

[7] R. Amirta, M.T. Haqiqi, S. Saparwadi, E. Septia, D. Mujiasih, K.A. Setiawan, M.A. Sekedang, Yuliansyah, A. Wijaya, B. Setiyono, W. Suwinarti, W., 2019. Searching for potential wood biomass for green energy feedstock: A study in tropical swamp-peat forest of Kutai Kertanegara, Indonesia. Biodiversitas Journal of Biological Diversity 2019, 20(6), pp.1516-1523. DOI: https://doi.org/10.13057/biodiv/d200605.

[8] Yuliansyah, M.T. Haqiqi, E. Septia, D. Mujiasih, H.A. Septiana, K.A., Setiawan, B. Setiyono, E.M. Angi, N.M. Sari, I.W. Kusuma, W. Suwinarti, R. 
Amirta, Diversity of plant species growing during fallow period of shifting cultivation and potential of its biomass for sustainable energy production in Mahakam Ulu, East Kalimantan, Indonesia. Biodiversitas Journal of Biological Diversity 2019, 20(8), pp.2236-2242 DOI: https://doi.org/10.13057/biodiv/d200818.

[9] M. Henry, A. Besnard, W.A. Asante, J. Eshun, S. Adu-Bredu, R. Valentini, M. Bernoux, L. SaintAndré, Wood density, phytomass variations within and among trees, and allometric equations in a tropical rainforest of Africa. Forest Ecology and Management 2010, 260(8), pp.1375-1388. DOI: https://doi.org/10.1016/j.foreco.2010.07.040.

[10] L. Parikh, S.A. Channiwala, G.K. Ghosal, A correlation for calculating elemental composition from proximate analysis of biomass materials. Fuel 2007, 86, pp.1710-1719. DOI: https://doi.org/10.1016/j.fuel.2006.12.029.

[11] I. Jusoh, F.A. Zaharin, N.S. Adam, Wood quality of Acacia hybrid and second-generation Acacia mangium. Bioresources 2014, 9(1), pp.150-160.

[12] R.I.C. Lumbres, Y.J. Lee, C.W. Yun, C.D. Koo, S.B. Kim, Y.M. Son, K.H. Lee, H.K. Won, S.C. Jung, Y.O. Seo, DBH-height modeling and validation for Acacia mangium and Eucalyptus pellita in Korintiga Hutani Plantation, Kalimantan, Indonesia. Forest science and technology 2015, 11(3), pp.119-125. DOI: https://doi.org/10.1080/21580103.2014.957356.

[13] L. Corpataux, S. Okuda, H.W. Kua, Panel and plate properties of Cross-laminated timber (CLT) with tropical fast-growing timber species in compliance with Eurocode 5. Construction and Building Materials 2020, 261, p.119672. DOI: https://doi.org/10.1016/j.conbuildmat.2020.119672

[14] A. Demirbas, Higher heating values of lignin types from wood and non-wood lignocellulosic biomasses. Energy Sources, Part A: Recovery, Utilization, and Environmental Effects 2017, 39(6), pp.592-598.

DOI: https://doi.org/10.1080/15567036.2016.1248798.

[15] F. Francescato, E. Antonini, L.Z. Bergomi, Wood fuels handbook: production, quality requirements, trading. AIEL-Italian Agriforestry Energy Association 2008, Legnaro. Italy.

[16] B. Günther, K. Gebauer, R. Barkowski, M. Rosenthal, C.T. Bues, Calorific value of selected wood species and wood products. European Journal of Wood and Wood Products 2012, 70(5), pp.755-757. DOI: https://doi.org/10.1007/s00107012-0613-z.
[17] D. Komilis, K. Kissas, A. Symeonidis, Effect of organic matter and moisture on the calorific value of solid wastes: An update of the Tanner diagram. Waste management 2014, 34(2), pp.249-255. DOI: https://doi.org/10.1016/j.wasman.2013.09.023.

[18] R. Tabakaev, I. Shanenkov, A. Kazakov, A. Zavorin, Thermal processing of biomass into highcalorific solid composite fuel. Journal of analytical and applied pyrolysis 2017, 124, pp.94-102. DOI: https://doi.org/10.1016/j.jaap.2017.02.016.

[19] A. Özyuğuran, S. Yaman, Prediction of calorific value of biomass from proximate analysis. Energy Procedia 2017, 107, pp.130-136. DOI: https://doi.org/10.1016/j.egypro.2016.12.149.

[20] W. Li, Q. Dang, R.C. Brown, D. Laird, M.M. Wright, The impacts of biomass properties on pyrolysis yields, economic and environmental performance of the pyrolysis-bioenergy-biochar platform to carbon negative energy. Bioresource technology 2017, 241, pp.959-968. DOI: https://doi.org/10.1016/j.biortech.2017.06.049.

[21] R.J. Stirling, C.E. Snape, W. Meredith, The impact of hydrothermal carbonization on the char reactivity of biomass. Fuel Processing Technology 2018, 177, pp.152-158. DOI: https://doi.org/10.1016/j.fuproc.2018.04.023.

[22] A.I. Anukam, B.P. Goso, O.O. Okoh, S.N. Mamphweli, Studies on characterization of corn cob for application in a gasification process for energy production. Journal of Chemistry 2017, 6478389.

DOI: https://doi.org/10.1155/2017/6478389.

[23] A. Balraj, J. Krishnan, K. Selvarajan, K. Sukumar, Potential use of biomass and coal-fine waste for making briquette for sustainable energy and environment. Environmental Science and Pollution Research 2020, pp.1-7. DOI: https://doi.org/10.1007/s11356-020-10312-2.

[24] V. Pasangulapati, K.D. Ramachandriya, A. Kumar, M.R. Wilkins, C.L. Jones, R.L. Huhnke, Effects of cellulose, hemicellulose and lignin on thermochemical conversion characteristics of the selected biomass. Bioresource Technology 2012, 114, pp.663-669. DOI: https://doi.org/10.1016/j.rser.2012.12.025.

[25] Z. Dong, Z. Liu, X. Zhang, H. Yang, J. Li, S. Xia, Y. Chen, H. Chen, Pyrolytic characteristics of hemicellulose, cellulose and lignin under $\mathrm{CO}_{2}$ atmosphere. Fuel 2019, 256, p.115890. DOI: https://doi.org/10.1016/j.fuel.2019.115890. 